\title{
ENDOVENOUS LASER ABLATION OF THE GREAT SAPHENOUS VEIN IN PATIENTS WITH VON WILLEBRAND DISEASE
}

Nikola Mirkovic ${ }^{1}$, Bozidar Novakovic ${ }^{1}$, Zarko Sretenovic ${ }^{1}$, Snezana Sretenovic ${ }^{2}$, Predrag Djurdjevic ${ }^{2,3}$ ${ }^{1}$ Department of Vascular Surgery, Clinical Centre of Kragujevac, Kragujevac, Serbia;

${ }^{2}$ Clinic of Hematology, Clinical Centre of Kragujevac, Kragujevac, Serbia;

${ }^{3}$ Faculty of Medical Sciences, University of Kragujevac, Kragujevac, Serbia.

\section{ENDOVENSKA LASERSKA ABLACIJA VELIKE SAFENSKE VENE KOD PACIJENTA SA "VON WILLEBRAND"-OVOM BOLEŠĆU \\ Nikola Mirkovići ${ }^{1}$, Božidar Novaković ${ }^{1}$, Žarko Sretenović ${ }^{1}$, Snežana Sretenović ${ }^{2}$, Predrag Đurđević ${ }^{2,3}$ \\ ${ }^{1}$ Odsek vaskularne hirurgije, Klinicki centar Kragujevac, Kragujevac, Srbija; \\ ${ }^{2}$ Klinika za hematologiju, Klinicki centar Kragujevac, Kragujevac, Srbija; \\ ${ }^{3}$ Fakultet medicinskih nauka, Univerzitet u Kragujevcu, Kragujevac, Srbija}

\section{ABSTRACT}

\section{Introduction}

Patients with von Willebrand disease have a high risk of bleeding during the surgical treatment of varicose veins. Endovenous laser ablation (EVLA) of the great saphenous vein (GSV) is a minimally invasive treatment for saphenofemoral junction incompetence. The number of complications and relapse rate of EVLA are lower than in those of conventional surgical treatment.

\section{Case presentation}

A patient with great saphenous vein insufficiency, von Willebrand disease and hypofibrinogenemia successfully underwent endovenous laser ablation. Replacement therapy with cryoprecipitate was administered preoperatively and postoperatively. The surgical procedure and postoperative course were unremarkable.

\section{Conclusion}

In patients with von Willebrand disease and other coagulation disorders, endovenous laser ablation is a safe and effective treatment. The use of minimally invasive treatment, the adequate correction of haemostasis, and close cooperation between the haematologist, anaesthesiologist and endovascular surgeon reduce the risk of bleeding.

Key words: Von Willebrand disease; varicose veins; surgery; endovenous laser ablation; great saphenous vein;

\section{SAŽETAK}

\section{Uvod}

Kod pacijenata sa von Willebrand-ovom bolešću pri operativnom lečenju varikoznih vena postoji povišen rizik od krvavljenja. Endovaskularna laserska ablacija velike vene safene je minimalno invazivna metoda lečenja insuficijencije safenofemoralnog ušća. U odnosu na klasičan hirurški tretman manji je broj komplikacija i recidiva.

\section{Prikaz slučaja}

Pacijentkinja sa insuficijencijom velike vene safene, von Willbrand-ovom bolešću i hipofibrinogenemijom uspešno je operisana laserskom ablacijom vene. Preoperativno $i$ postoperativno ordinirana je supstituciona terapija krioprecipitatom. Operativni zahvat i postoperativni tok protekao je uredno.

\section{Zaključak}

Kod pacijenata sa von Willebrand-ovom bolešću i drugim poremećajima koagulacije, endovaskularna laserska ablacija vene je sigurna i efikasna metoda lečenja. Primenom minimalno invazivnih metoda lečenja, adekvatnom korekcijom hemostaze, saradnjom hematologa, anesteziologa $i$ endovaskularnog hirurga smanjuje se rizik za nastanak krvavljenja.

Ključne reči: Von Willebrand-ova bolest; varikozne vene; hirurgija; endovaskularna laserska ablacija; velika vena safena

\section{INTRODUCTION}

Von Willebrand disease (vWD) is the most common congenital haemorrhagic syndrome, characterised by a variety of quantitative and/or qualitative abnormalities in von Willebrand factor (vWF) $)^{1,2}$. Mutations, deletions and vWF gene polymorphisms cause $\mathrm{vWD}^{3}$. The inheritance is usually autosomal dominant, while severe forms are inherited recessively. There are three main subtypes; type 1 refers to a quantitative deficiency of vWF, while vWF and F VIII are

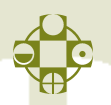

qualitatively normal in approximately $80 \%$ of cases $^{4}$; type 2 includes qualitative defects, and type 3 is defined as a complete lack of $\mathrm{vWF}^{5}$. vWF is a protein that mediates platelet adhesion and aggregation at the site of vascular injury and serves as a carrier for factor VIII, extending its halflife from approximately 2 hours (in the absence of vWF) to 8-12 hours. An abnormality of vWF can manifest as a primary haemostasis disorder ${ }^{1,6}$ with a prevalence of $0.86 \%$ 
to $1.6 \%{ }^{7-10}$. The prevalence is twice as high in women as in men, likely because menorrhagia contributes to a more frequent diagnosis, particularly of milder forms ${ }^{8}$. The likelihood of bleeding depends on the vWD subtype and the level of vWF deficiency ${ }^{11}$.

In patients with vWD who require surgery or other invasive procedures, it is necessary to adequately maintain haemostasis preoperatively and postoperatively to prevent bleeding ${ }^{12,13}$. Three main therapeutic modalities are used for the treatment of VWD: desmopressin (1-deamino-8-Darginine vasopressin, DDAVP) acetate, plasma derivatives (complex concentrate FVIII/vWF; cryoprecipitate) and antifibrinolytics ${ }^{2,5,12-20}$. If bleeding occurs, it is important to determine whether it resulted from surgery or inadequate haemostasis.

Early treatment of great saphenous vein insufficiency (GSV) is recommended ${ }^{21}$ in saphenofemoral reflux. Classical surgical techniques and endovascular treatment are applied in CEAP class $C$ primary chronic venous insufficiency (CVI) ${ }^{22}$. Clinical relapses were not significantly different between EVLA or endovenous radiofrequency ablation and surgery ${ }^{23}$. Endovenous ablation has advantages in decreasing the incidence of pain, haematoma, and wound infection and ain permitting a more rapid return to work ${ }^{23}$. Endovenous laser ablation (EVLA) is applied in the treatment of superficial and perforating venous reflux. EVLA is a safe and effective treatment for GSV insufficiency ${ }^{24-27}$. Relapse after EVLA is 3-5\%, whereas that in conventional surgery is $20-40 \%$ within 5 years ${ }^{26}$.

\section{CASE PRESENTATION}

We investigated a female patient, 44 years of age, with vWD, hypofibrinogenemia and popliteal and thigh varicose veins. Stage C3 GSV insufficiency was determined using preoperative Doppler colour flow mapping (CDS).

In her personal history, the patient had excessive menstruation and postpartum bleeding. After the second birth, accompanied by heavy and delayed postpartum bleeding, the diagnosis of type I von Willebrand disease was established, along with hypofibrinogenemia of unknown origin. She reported no other diseases. There was no information about hereditary diseases or a tendency to haemorrhage among immediate family members.

Slightly prolonged bleeding time, as measured by the Duke method (4 min $30 \mathrm{sec}$ ), slightly lower levels of vWF (49.2\%) and lower fibrinogen levels (1.706 g/l) were detected preoperatively. The concentrations of coagulation factors, complete blood count and hepatogram were within the normal range. A haematologist and anaesthesiologist were consulted preoperatively because of the patient's risk of bleeding. Preoperative and postoperative cryoprecipitate replacement therapy was given due to the simultaneous lack of fibrinogen and type 1 von Willebrand disease. After adequate preoperative preparation, the corrected haemostasis parameters were within the reference range.

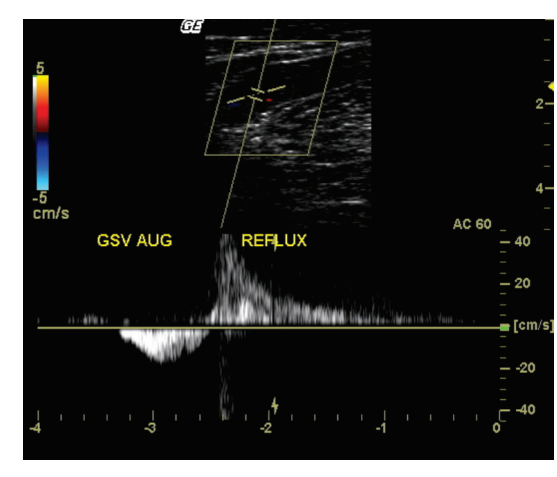

GSV insufficiency

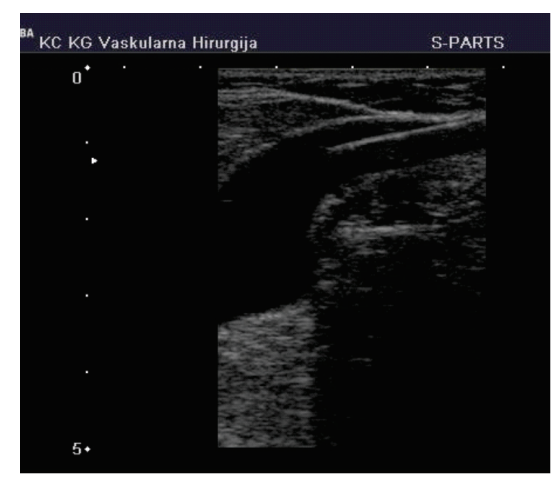

Biolitec catheter positioned at GSV junction

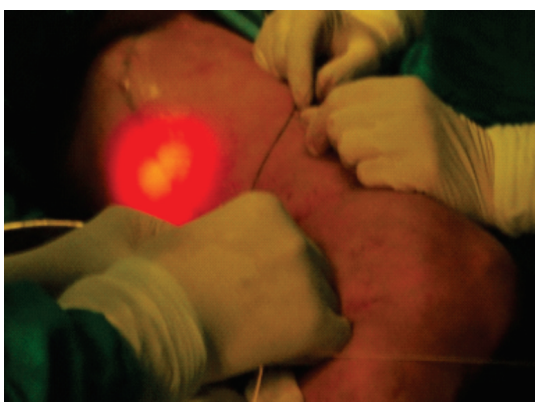

Figure 3.

GSV laser ablation

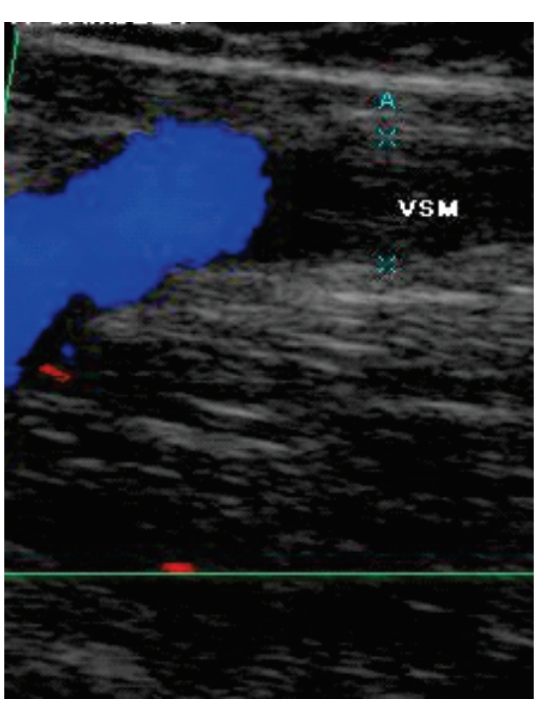

cclusion of the GSV junction after EVLA

The patient underwent EVLA treatment of the GSV using $1470 \mathrm{~nm}$ (Biolitec) 6F catheter and CDS monitoring. During the operation, CDS-guided vein catheterisation was performed along with catheter positioning, tumescent infiltration, laser energy administration and postoperative control. Total intravenous anaesthesia was applied with tu- 
mescent local anaesthesia and intraoperative monitoring. The operative course was uncomplicated. The patient was mobile $2 \mathrm{~h}$ after the intervention.

On the first and second postoperative days, the fibrinogen values were $1.910 \mathrm{~g} / \mathrm{l}, 2.214 \mathrm{~g} / \mathrm{l}$ and $2.880 \mathrm{~g} / \mathrm{l}$. The bleeding time measurements and haematological parameters remained within the normal range.

The patient was discharged from hospital in good general condition with no local complications $48 \mathrm{~h}$ after the intervention. She was monitored from postoperative days 7-30. Postoperatively, graduated elastic compression stockings (23-32 $\mathrm{mmHg}$ ) were applied, and sclerosant foam was injected into the varicose veins (in an outpatient setting) as sclerotherapy for GSV varicose tributaries and reticular veins.

\section{DISCUSSION}

In patients with vWD, the aim of surgical treatment is to apply sufficiently effective therapy with minimal risk of bleeding. Erik von Willebrand contributed to the discovery and treatment of vWD when he first described the haemorrhagic syndrome in a 5-year-old girl and her family members in 1926. Zimmerman identified the antigen associated with F VIII and called it vWF ${ }^{1}$.

The surgical treatment of patients with von Willebrand disease is complex. In our patient, although in its mild form, type 1 von Willebrand disease was further complicated by hypofibrinogenemia of unknown aetiology. The hereditary haemorrhagic diathesis in these patients increases the risk of bleeding during surgical intervention, and follow-up care is more complicated. Through adequate preoperative and postoperative replacement, the coagulation factors were corrected, and the risk of bleeding was minimised ${ }^{12-20}$.

If venous reflux is not treated appropriately, it can lead to disease progression, the development of superficial thrombophlebitis, vein rupture and bleeding, and the occurrence of venous ulcers and skin lesions. The extensive classical surgical ligation and stripping of varicose veins due to GSV insufficiency has a high risk of bleeding associated with a number of intraoperative and postoperative complications compared with endovenous ablation ${ }^{22-34}$. The application of minimally invasive EVLA or GSV with adequate correction of haemostasis according to the type of vWD minimizises the risk to the patient, with satisfactory healing of CVI. EVLA exceeds traditional surgical treatment for fewer complications, shorter hospitalisation, reduced treatment costs and more rapid return to daily life activities. The patient subjectively feels better, with less postoperative pain, and the aesthetic outcome is more favourable ${ }^{27-34}$.

\section{CONCLUSIONS}

In patients with von Willebrand disease and other coagulation disorders, endovenous laser ablation is the method of choice when surgical treatment of the GSV insufficiency is necessary. The use of minimally invasive methods, appropriate prophylaxis, and intraoperative and perioperative monitoring reduces the risk of bleeding. Through adequate cooperation among haematologists, anaesthesiologists and endovascular surgeons, laser ablation of the GSV in patients with coagulation disorders can be performed safely and effectively.

\section{ACKNOWLEDGEMENTS}

This study was partially financed by the Grant No 175007 from Serbian Ministry of Education and by the Grant No 01-404 from the Ministry of Science, Montenegro.

\section{REFERENCES}

1. Kreuz W. von Wilebrand's disease: from discovery to therapy - milestones in the last 25 years. Haemophilia 2008; 14 (5): 1-2.

2. Federici AB. Diagnosis of inherited von Willebrand disease: a clinical perspective. Semin Thromb Hemost 2006; 32 (6): 555-65.

3. Ginsburg D, Wagner DD. Structure, biology and genetics of von Willebrand factor.In:Hofman of Hematology, Basic Princips and Practice, Elsevier Churchill Livingstone. $5^{\text {th }}$ ed. $2008 ; 1953-59$.

4. Grabowski EF, Curran MA, Van Cott EM. Assessment of a cohort of primary pediatric patients with presumptive diagnosis of type 1 von Willebrand disease with a novel high shear rate, non- citrated blood flow device. Thromb Res. Apr 2012; 129 (4): e-18-24.

5. Sadler JE, Budde U, Eikenboom JC et al. Update on the pathophysiology and classification of von Willebrand disease. a report of the Subcommettee on von Willebrand factor. J Throm Haem 2006; 4: 2103-14.

6. Rick ME, Walsh CE, Key NS. Congenital bleeding disorders. Hematology Am Soc Hematol Educ Program 2003; $559-74$.

7. Ginsburg D, Wagner DD. Structure, biology and genetics of von Willebrand factor. In: Hofman et al. Hematology, Basic principles and Practice, Elsevier Churchill Livingstone. 4th ed. 2005; 1937- 58.

8. Sadler EJ. Von Willebrand disease type I: a diagnosis in search of disease. Blood 2003; 101 (6): 2089-93.

9. Rodeghiero F, Castaman G, Dini E. Epidemiological investigation of the prevalence of von Willebrand's disease. Blood 1987; 69 (2): 454-9.

10. Franchini M. Surgical prophylaxis in von Willebrand's disease: a difficult balance to manage. Blood Transfus 2008; 6 Suppl 2: s33-8.

11. Castaman G, Federici AB, Rodeghiero F, et al. Review Von Willebrand's disease in the year 2003: towards the complete identification of gene defects for correct diagnosis and treatment. Haematologica 2003; 88 (1): 94-108. 
12. Franchini M, Targher G, Lippi G. Review Prophylaxis in von Willebrand disease. Ann Hematol 2007; 86 (10): 699-704.

13. Federici AB, Baudo F, Caracciolo C, et al. Clinical efficacy of highly purified, doubly virus-inactivated factor VIII/von Willebrand factor concentrate (Fanhdi) in the treatment of von Willebrand disease: a retrospective clinical study. Haemophilia 2002; 8: 761-7.

14. Mannucci PM, Chediak J, Hanna W, et al. The Alphanate Study Group. Treatment of von Willebrand disease with a high-purity factor VIII/von Willebrand factor concentrate: a prospective, multicenter study. Blood 2002; 99: 450-6..

15. Franchini M, Rossetti G, Tagliaferri A, et al. Efficacy and safety of factor VIII/von Willebrand factor concentrate (Haemate-P) in preventing bleeding during surgery or invasive procedures in patients with von Willebrand's disease. Haematologica 2003; 88: 1279-83.

16. Thompson AR, Gill JC, Ewenstein BM, et al. Humate-P Study Group. Successful treatment for patients with von Willebrand disease undergoing urgent surgery using factor VIII/von Willebrand factor concentrate $(\mathrm{Hu}-$ mate-P) Haemophilia 2004; 10: 42-51.

17. Bernstein J, Cox Gill J, Leissinger CA, et al. Humate P Study Group. Safety and efficacy of von Willebrand factor/factor VIII concentrate (Humate-P) for prophylaxis of excessive bleeding during elective surgery un patients with von Willebrand disease. Blood 2006; 108 abstract 4076.

18. Federici AB, Castaman G, Franchini M, et al. Clinical use of Haemate P in inherited von Willebrand disease: a cohort study on 100 Italian patients. Haematologica 2007; 92: 944-51.

19. Lethagen S, Kyrle PA, Castaman G, et al. The Haemate P Surgical Study Group. Von Willebrand factor/factor VIII concentrate (Haemate P) dosing based on pharmacokinetics: a prospective multicenter trial in elective surgery. J Thromb Haemost 2007; 5: 1420-30.

20. Borel-Derlon A, Federici AB, Roussel-Robert V, et al. Treatment of severe von Willebrand disease with a high-purity von Willebrand factor concentrate (Wilfactin): a prospective study of 50 patients. J Thromb Haemost 2007; 5: 1115-24.

21. Chastanet S, Pittaluga P. Patterns of reflux in the great saphenous vein system. Phlebology 2013; 28 Suppl 1: 39-46.

22. Siribumrungwong B, Noorit P, Wilasrusmee C, et al. A systematic review and meta-analysis of randomised controlled trials comparing endovenous ablation and surgical intervention in patients with varicose vein. Eur J Vasc Endovasc Surg 2012; 44(2): 214-23.

23. Eklöf B, Rutherford RB, Bergan JJ et al. American Venous Forum International Ad Hoc Committee for Revision of the CEAP Classification. Revision of the CEAP classification for chronic venous disorders: consensus statement. J Vasc Surg 2004; 40(6): 1248-52.

24. Carradice D, Mekako AI, Mazari FA, et al. Clinical and technical outcomes from a randomized clinical trial of endovenous laser ablation compared with conventional surgery for great saphenous varicose veins. Br J Surg 2011; 98 (8): 1117-23.

25. Firouznia K, Ghanaati H, Hedayati $M$, et al Endovenous laser treatment (EVLT) for the saphenous reflux and varicose veins: a follow-up study. J Med Imaging Radiat Oncol 2013; 57 (1): 15-20.

26. Fischer R, Linde N, Duff C, et al. Late recurrent saphenofemoral junction reflux after ligation and stripping of the greater saphenous vein. J Vasc Surg 2001; 34: 236-40.

27. Chen JQ, Xie H, Deng HY, et al. Endovenous laser ablation of great saphenous vein with ultrasound-guided perivenous tumescence: early and midterm results. Chin Med J (Engl) 2013; 126 (3): 421-5.

28. Zafarghandi MR, Akhlaghpour S, Mohammadi H, et al. Endovenous laser ablation (EVLA) in patients with varicose great saphenous vein (GSV) and incompetent saphenofemoral junction (SFJ): an ambulatory single center experience. Vasc Endovascular Surg 2009; 43 (2): 178-84.

29. Luebke T, Brunkwall J. Systematic review and meta-analysis of endovenous radiofrequency obliteration, endovenous laser therapy, and foam sclerotherapy for primary varicosis. J Cardiovasc Surg (Torino) 2008; 49: 213-33.

30. Van den Bos R, Arends L, Kockaert M, et al. Endovenous therapies of lower extremity varicosities: a meta-analysis. J Vasc Surg 2009; 49: 230-39.

31. Flessenkämper I, Hartmann M, Stenger D, et al. Endovenous laser ablation with and without high ligation compared with high ligation and stripping in the treatment of great saphenous varicose veins: initial results of a multicentre randomized controlled trial. Phlebology $2013 ; 28$ (1): 16-23.

32. Rasmussen LH, Bjoern L, Lawaetz M, et al. Randomized trial comparing endovenous laser ablation of the great saphenous vein with high ligation and stripping in patients with varicose veins: short-term results. J Vasc Surg 2007; 46 (2): 308-15.

33. Christenson JT, Gueddi S, Gemayel G, et al. Prospective randomized trial comparing endovenous laser ablation and surgery for treatment of primary great saphenous varicose veins with a 2 -year follow-up. J Vasc Surg 2010; 52 (5): 1234-41.

34. Darwood RJ, Theivacumar N, Dellagrammaticas D, et al. Randomized clinical trial comparing endovenous laser ablation with surgery for the treatment of primary great saphenous varicose veins. Br J Surg 2008; 95 (3): 294-301. 